\begin{tabular}{|c|c|}
\hline \multicolumn{2}{|c|}{ PublisherInfo } \\
\hline PublisherName & Palgrave Macmillan UK \\
\hline PublisherLocation & London \\
\hline PublisherImprintName & Palgrave Macmillan \\
\hline
\end{tabular}

\title{
Quality-adjusted labour input: estimates for 1996 to 2006
}

\begin{tabular}{|c|c|}
\hline \multicolumn{2}{|c|}{ ArticleInfo } \\
\hline ArticleDOI & 10.1057/palgrave.elmr.1410187 \\
\hline ArticleCategory & Feature \\
\hline ArticleFirstPage & 48 \\
\hline ArticleLastPage & 54 \\
\hline ArticleHistory & $\begin{array}{ll}\text { RegistrationDate } & : 2007-12-17 \\
\text { OnlineDate } & : \text { 2007-12-17 }\end{array}$ \\
\hline ArticleCopyright & Crown copyright 2007 \\
\hline
\end{tabular}




\section{Sumit Dey-Chowdhury, ${ }^{\text {Aff1 }}$ \\ Peter Goodridge, ${ }^{\text {Aff1 }}$}

\section{Presents experimental data for the above for the UK and for a broad six- industry breakdown}

Estimates of quality-adjusted labour input are improved measures of labour's input to production and are therefore more suitable for analysing and modelling productivity than standard volume measures of hours or workers. The estimates incorporate both the quantity and quality components of hours worked. This article presents experimental quality-adjusted labour input estimates for 1996 to 2006 for the UK and for a broad six-industry breakdown. Recent development work has also allowed quality-adjusted labour input estimates to be published for the market sector.

Misc

The Full Text of this article can be found on the National Statistics website (http://www.statistics.gov.uk/cci/article.asp?id=1906). 